\title{
Evaluation Of Supplementary Feeding (Pmt) Program For Treatment Of Poor Nutrition To Children In North Aceh District
}

\author{
By \\ Mauludi ${ }^{1}$, Alwi, ${ }^{1}$ Teuku Alfiady ${ }^{1}$ \\ 1,Public Administration Departement, Faculty of Sosial and Political Sciences, Universitas Malikussaleh, \\ Lhokseumawe, Indonesia \\ Email : mauludi@unimal.ac.id
}

\begin{abstract}
Malnutrition is one of the most concerning things that happened in Aceh Utara district, because it is a disgrace to the government and society. Based on data from the North Aceh Health Office, the number of sufferers of malnutrition is increasing every year. This study aims to identify and describe the evaluation of the program for handling malnutrition under five and the obstacles to evaluating the program for handling malnutrition under five by the government in North Aceh Regency. This study uses a qualitative approach with descriptive analysis research type. Data collection techniques were carried out by observation, interviews, and documentation, the data obtained were analyzed using an interactive analysis model. The results showed that government programs exist and have been implemented, namely the Supplementary Food Provision (PMT) program in the form of milk, biscuits, and multivitamins, but the number of sufferers of malnutrition is still increasing every year because the implementation is not comprehensive and uneven, which is an obstacle. In the Supplementary Feeding Program (PMT), there is an inadequate budget and a large area accompanied by a lack of supervision from the Health Office so that this program has not been carried out optimally. Research recommendations, the government can make efforts to prevent malnutrition in accordance with the rules set out in Law no. 36 of 2009 concerning health to improve the nutritional quality of individuals and communities in accordance with advances in science and technology.
\end{abstract}

Keywords: Program, evaluation, Malnutrition, Supplementary, Government

\section{Introduction}

\section{Background of the problem}

National development is the continuous improvement of the quality of human resources (HR). Efforts to improve the quality of human resources begin with the main concern on the process of child growth and development from conception to young adulthood. During this period of growth and development, the fulfillment of children's basic needs such as care and nutritional food that is given with love can form healthy, intelligent and productive human resources.

Malnutrition is a condition in which a person is declared to be undernourished, or his nutritional status is below the average standard. Nutrients in question can be in the form of protein, carbohydrates, and calories. Malnutrition is still an unresolved problem to date. The problem of malnutrition and malnutrition has become a global concern because sufferers of malnutrition are generally toddlers and children who are none other than the nation's next generation. The case of malnutrition is a disgrace to the government and society because it occurs in the midst of the rapid progress of the times. For this reason, this problem has always been a special handling program by the government.

In an effort to overcome the problem of malnutrition in children under five, the Ministry of Health has established a comprehensive policy, including prevention, promotion/education and prevention of 
Internasional Journal Of Public Administration Studies, 1 (1) (2021) 1-01

Volume 1 Number I, 2021-06-01

\section{e ISSN}

malnutrition. Prevention efforts are carried out through monitoring growth at the posyandu. The handling of undernourished toddlers is done by providing additional food (PMT) while malnourished toddlers must receive treatment according to the existing management of malnourished toddlers. To improve the quality of nutrition services in handling malnourished children, it is carried out through training in the management of malnutrition for health workers in health facilities.

To realize health for the community, the government is responsible for providing adequate health care facilities and equality for everyone. The government's responsibility to provide health services in an effort to improve public nutrition is specifically regulated in Law Number 36 of 2009 concerning Health, which aims to improve the nutritional quality of individuals and communities, through improving food consumption patterns, improving nutrition-conscious behavior, increasing access to quality services. nutrition and health in accordance with advances in science and technology.

In Qanun Aceh Utara No. 33 of 2005 concerning health, it is stated that nutrition services are carried out to realize nutritional improvements in the entire life cycle from in the womb to the elderly with priority to nutritional vulnerable groups. school age and adolescent girls, pregnant women, postpartum and breastfeeding, female workers, and the elderly. This nutrition service is carried out in health care facilities, other institutions/facilities, communities, and locations with emergency situations.

Based on data from the Aceh Health Office, the number of children suffering from malnutrition in 2021 in Aceh province reached
307 cases, and the highest was in North Aceh reaching 79 cases of malnutrition. The head of the Aceh Health Service, dr. M. Yani, M.Kes through the Head of Nutrition Office said that this figure has decreased when compared to 2014 which reached 341 cases of malnutrition in Aceh.

\begin{tabular}{|c|c|c|}
\hline No & Region Name & $\begin{array}{l}\text { Number of } \\
\text { Cases }\end{array}$ \\
\hline 1 & Simeulu & 8 \\
\hline 2 & Aceh Singkil & 6 \\
\hline 3 & South Aceh & 15 \\
\hline 4 & Southeast Aceh & 3 \\
\hline 5 & North Aceh & 79 \\
\hline 6 & East Aceh & 19 \\
\hline 7 & Central Aceh & 2 \\
\hline 8 & West Aceh & 14 \\
\hline 9 & Aceh Besar & 21 \\
\hline 10 & Pidie & 15 \\
\hline 11 & Bireuen & 27 \\
\hline 12 & Abdya & 5 \\
\hline 13 & Gayo Lues & 2 \\
\hline 14 & Aceh Tamiang & 8 \\
\hline 15 & Nagan Raya & 12 \\
\hline 16 & Aceh Jaya & 2 \\
\hline 17 & Really Merry & 2 \\
\hline 18 & Pidie Jaya & 7 \\
\hline 19 & Banda Aceh & 5 \\
\hline 20 & Sabang & 3 \\
\hline 21 & Langsa & 1 \\
\hline 22 & Lhokseumawe & 10 \\
\hline 23 & Subulussalam & 12 \\
\hline
\end{tabular}

(Source Aceh Provincial Health Office 2021)

Based on the table above, the number of cases of malnutrition in a number of districts/cities in Aceh, North Aceh has increased in terms of malnutrition every year, this is certainly very worrying because malnutrition results in death if it is not 
Internasional Journal Of Public Administration Studies, 1 (1) (2021) 1-01

Volume 1 Number I, 2021-06-01

e ISSN

immediately addressed by health workers, it will have serious consequences. low intelligence, and weight and height in adulthood are lower than normal children, and are more often affected by infections such as coughs, colds, diarrhea, tuberculosis, and others due to decreased immunity.

The handling carried out by the government is the first that the Puskesmas nutrition officer sends data on under-five malnutrition after validation has been carried out first to the district/city health office, if the data for underfive malnutrition is valid and correct, it will be proposed to get Supplementary Feeding (PMT) Recovery, and then the Puskesmas provides the PMT Recovery materials to the Village Development Officers (PPD) according to the allocation of selected toddlers (Sourcehttp://www.acehportal.com/2728-2/

Based on the results of preliminary observations through the Serambi Daily Newspaper said that the toddler on behalf of Muhammad Alfatani (9) who came from the village of Sawang, North Aceh with a weight condition of only 4.3 kilograms, is currently being cared for by his grandmother, Marniah (44), while the two parents of the toddler were not with their child. DPD RI member from Aceh Haji Uma, also provided compensation in the form of cash which was received by Marniah for the purpose of feeding the poor baby. (Source http://aceh.tribunnews .com/2016/05/01/haji-uma-help-cancer-

suffering-and-malnutrition)

Based on the description of the phenomenon above, the writer is interested in conducting a study entitled "Evaluation of the Supplementary Feeding Program for Handling
Malnutrition in Toddlers in North Aceh Regency".

\section{Formulation of the problem}

Based on the background described above, this research examines the following matters:

a. Evaluation of the supplementary feeding program for handling malnutrition under five in North Aceh District?

b. What are the obstacles to the supplementary feeding program for handling malnutrition under five in North Aceh District?

\section{Research focus}

To clarify the scope of the problem in this research, it is necessary to determine the focus of the study. The focus of the study in this research is as follows:

a. To find out and describe the evaluation of the Supplementary Feeding program carried out by the government in North Aceh District

b. To find out and describe the obstacles to the Supplementary Feeding program carried out by the government in North Aceh District

\section{Research purposes}

The research objectives are:

a. To find out and describe the evaluation of the under-five malnutrition program carried out by the government in North Aceh District

b. This study aims to identify and describe the barriers to evaluating the program for handling malnutrition under five in North Aceh District. 
Internasional Journal Of Public Administration Studies, 1 (1) (2021) 1-01

Volume 1 Number I, 2021-06-01

e ISSN

\section{Benefits of research}

Basically, this research is very useful for the author and also for the Lhokseumawe City Government, especially the Health Office.

1. Theoretical Benefits.

a. The results of this study are expected to be an additional reference for further research.

b. The results of this study are expected to add insight and knowledge to readers.

2. Practical Benefits.

a. To get a detailed picture of the implementation of policies for handling malnutrition under five in North Aceh District, as well as the Barriers to the Implementation of Policies for handling malnutrition under five in North Aceh District

\section{Research Method}

\section{Research Design}

This research was designed through a qualitative approach with this type of descriptive research is research that seeks to describe the current problem solving based on data.

The approach used in this study is a descriptive qualitative analysis approach, according to Sugiyono (2006:11) is "a research approach used in data collection by examining the problems that are happening at this time, then the data is collected and compiled, after that it is processed. and analyzed". With this design approach, it is hoped that accurate and reliable information will be extracted.

\section{Research Mindset}

The research flow or roadmap of this research process can be described as follows:

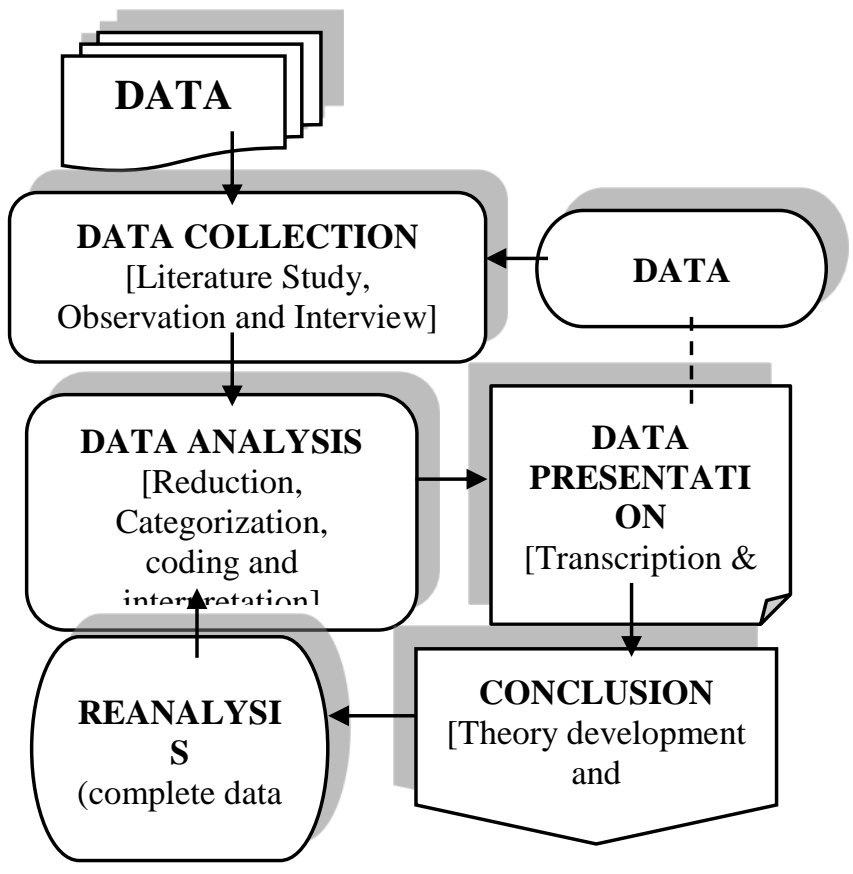

Research Objects and Subjects

The object of this research isevaluation of the supplementary feeding program (PMT) for handling malnutrition under five in North Aceh DistrictMeanwhile, the subject of this research is called a participant (informant/provider of information from across professions) in the people of North Aceh Regency. The criteria for informants, among others;Head of Public Health, Head of Nutrition and Family Health Section, Coordinator of Advocacy and Public Policy MaTA (Aceh Transparency Society), Community leaders, communities and others in the research area, willing to be participants/informants and willing to be interviewed.

\section{Research sites}

The research location was conducted in North Aceh District, Sawang District. The reason the author conducts research at this location is because there are cases of 
Internasional Journal Of Public Administration Studies, 1 (1) (2021) 1-01

Volume 1 Number I, 2021-06-01

\section{e ISSN}

malnutrition in North Aceh Regency which continue to increase every year, with various programs provided by the government that have not been able to reduce cases of malnutrition. So that researchers are interested in conducting research.

\section{Data collection technique}

The data collection techniques that the author uses include observation, interviews and documentation

\section{Observation (Observation)}

“Observation means paying attention and following. Paying attention and following in the sense of observing carefully and systematically the intended behavioral target (Herdiansyah, 2011: 131). The phenomenon observed is the behavior of the apparatus as program implementers in handling malnutrition under five. In this case the researcher uses observationnon-participant, where the researcher comes directly, observes and then records the behavior as it occurs in the actual situation of the object under study, however, in this case the researcher is not directly involved in the activity. The research objects that will be observed include:

a. Attitudes and behavior of officers, as program implementers that provide services to the community in handling malnutrition under five.

b. Facilities, see how the facilities provided by the government in the process of handling under-five malnutrition. Like the tools needed in handling.

c. Spatial planning, looking at the strategic location of health services that are easily accessible by the community.

\section{Interview (Interview)}

An interview is a conversation between two people, one of which aims to explore and obtain information for a particular purpose. In this study, the researcher used the technique ofunstructured interview. According to Herdiansyah (2011:124) said that "unstructured interviews are interviews that are very flexible in terms of questions and answers. The questions are very open, the answers are wider and varied, in unstructured interviews interview guidelines are still needed but only the central theme is used by researchers as control of the flow of conversation during the interview. The purpose of this interview is to understand a certain phenomenon or problem.

\section{Data Analysis Techniques}

Data Analysis Technique is one of the data processing techniques to examine a phenomenon or problem in order to produce empirical data, According to Silalahi (2009:339), "Qualitative data analysis is carried out if the empirical data obtained is qualitative data in the form of a collection of tangible words not series of numbers and cannot arranged in categories, classification structures. Data (in the form of words) may have been collected in a variety of ways (observations, interviews, document digests, tapes) and are usually "processed" before they are ready for use (through recording, typing, editing, or transcribing), but analysis Qualitative research still uses words that are usually arranged in an expanded text, and does not use mathematical or statistical calculations as analytical tools.

According to Miles and Huberman in Silalahi (2009:340) using an interactive model. The analysis activity consists of three activity flows that occur simultaneously, namely data 
Internasional Journal Of Public Administration Studies, 1 (1) (2021) 1-01

Volume 1 Number I, 2021-06-01

e ISSN

reduction, data presentation, and conclusion drawing/verification.

a. Data reduction

is a form of analysis that sharpens, categorizes, directs, discards unnecessary, and organizes data in such a way that final conclusions can be drawn and verified.

b. Data Presentation

Presentation of data is as a set of structured information that gives the possibility of drawing conclusions and taking action through the data presented. The most frequently used data presentation for qualitative data is in the form of narrative text such as charts, matrices, graphs.

c. Withdrawal of Conclusions / Verification

After the data is presented, verification or conclusion is drawn. The initial conclusions put forward are tentative and will change if they are not supported by strong evidence.

\section{Discussion}

Based on the results of research in the field and documentation obtained that efforts to prevent malnutrition by the North Aceh Regency government include holding a routine Posyandu program and providing supplementary food (PMT) which is carried out every month, then the North Aceh District Health Office also coordinates with personnel The nutrition officer (TPG) of the puskesmas carries out efforts to monitor the nutritional status (PSG) and increases the coverage of weighing children under five at the posyandu. This is done so that it is quickly detected if

there are toddlers who have a body weight below the red line (BGM). This activity is one way of screening and tracking if there is a toddler who has a weight below the red line, it can be quickly detected and immediately given treatment. Assessment of nutritional status is carried out based on anthropometric standards for assessing the nutritional status of children based on a decision from the Minister of Health of the Republic of Indonesia Number: 1995/MENKES/SK/XII/2010. In an effort to improve the quality of services, the government conducts training on malnutrition management for Nutrition Implementing Personnel (TPG) in the field.

Based on the results of interviews from the field related to the form of policy implementation that has been carried out by the government in overcoming the occurrence of malnutrition in the community, it has not been realized optimally. The forms of prevention carried out by the government such as holding routine posyandu which are carried out every month, but based on the results of field observations, posyandu procurement is rarely carried out in villages, where usually this activity is routinely carried out every month, not all villages hold regular posyandu every month, the weakening of posyandu procurement makes monitoring the growth of the nutritional status of children under five not running optimally,

The nutritional status of toddlers detected below the red line (BGM) is 124 and those who suffer from malnutrition are 27 toddlers. This illustrates that there are still many toddlers with nutritional status conditions that are below the standard line. The lack of community support (mothers of children under five) to weigh and check the 
Internasional Journal Of Public Administration Studies, 1 (1) (2021) 1-01

Volume 1 Number I, 2021-06-01

\section{e ISSN}

condition of the nutritional status of children

under five at the puskesmas and posyandu on a

regular basis is one of the unresolved problems,

so that every year it continues to be found that

children with nutritional status are below the

red line and then left, do not get treatment and

do not receive treatment. accompanied by the correct pattern and then the status changes to malnutrition.

Based on the results of field research that to improve the health status of children, the government conducts nutrition management training for nutrition implementers (TPG) in the field, where training is carried out at the district/city level by a team of facilitators. The trained health workers come from Puskesmas, Sub-Puskesmas and Poskesdes, involving the following health workers: (1) Puskesmas: doctors, nutritionists (TPG), nurses, health promotion workers; (2) Supporting Health Center: nurse or midwife; (3) Poskesdes: village midwife.

Based on the results of research in the field that training is rarely carried out for health workers, usually training is carried out every 6 months, but from field results in 2013 health workers did not receive training from the facilitator team. From the various forms of policy implementation that have been carried out, the reality in the field has not given optimal results because it is closely related to the still weak posyandu activities and the declining performance of health workers so that they have not been able to solve the problem completely in preventing malnutrition.

\section{Conclusion}

Based on the results of the focus in the formulation of the problem, the conclusions in this study are:

1. Evaluation of the program for handling malnutrition under five in the district in handling various forms of policy implementation starting from; Prevention carried out since in the womb by examining the measurement of upper arm circumference (LiLA) and hemoglobin $(\mathrm{Hb})$ in pregnant women to prevent the birth of babies with low body weight and routine posyandu to monitor the nutritional status of toddlers, and to improve health services provide health care training like malnutrition to TPG. In promotion/education, the government conducts socialization through PHBS counseling and exclusive breastfeeding to posyandu coordinators, and the prevention of malnutrition is carried out by special handling such as procurement of PMT, vitamins and medicines for 90 days, and outpatient referrals to pediatricians for people with malnutrition. ,

2. Barriers to the implementation of policies for handling malnutrition under five in North Aceh Regency, where there is a policy content related to the implementation process in accordance with procedures, one of which is related to the budget provided by the Government for handling malnutrition, which is still very limited, even for the provision of PMT. , vitamins and medicines are only given in 90 days, if during the recovery period the patient has not improved then the assistan cannot be continued, must wait for the budg in the following year. In addition, in implementing policies for handling malnutrition, there are still very limited health 
Internasional Journal Of Public Administration Studies, 1 (1) (2021) 1-01

Volume 1 Number I, 2021-06-01

e ISSN

personnel in the process of implementing

malnutrition.

and Determining the Quality of Education on Various Educational Components, Padang : Padang State University

\section{References}

Arikunto, 2004, Program Evaluation:

Yogyakarta, Student Library

Arikunto et al, 2009, Evaluation of Educational Programs: Yogyakarta, Pustaka Pelajar

Boulmetis \& Dutwin, (2005). Program Evaluation Government. Hisrich, New York

Devine, P. (1999). Using Logic Models in Substance Abuse Treatment Evaluation.

Eiseman, (2006), Logic Model Evaluation, Hisrich, New York

Ellis Salsabila (2013), Public Evaluation Model. Jakarta: Earth Literacy

Endang Mulyatiningsih (2011: 114), Evaluation of Policy Programs, Jakarta, Various Media

Fahmal (2006), Indonesian Government System, Jakarta: Earth Literacy

Frechtling, A. (2007). Logic Modeling Program Evaluation. Hisrich, New York

Herdiansyah (2011) Qualitative Research Methods, Yogyakarta, Student Library

Kellogg, WK. (2004). Logic Model Development Guide. Michigan : Battle Creek

Syafi'ie, 2004. Government System. Jakarta : Rineka Cipta

Tayipnapis in Farida. 2008. Program Evaluation. Jakarta : Rineka Cipta

Teguh, 2014, Community Nutrition Health, Jakarta: Earth Literacy

Widjaja, 2007, Local Government System: Yogyakarta, Pustaka Pelajar

Yusuf, 2005, Evaluation of Education as a Pillar of Information Providers and Activities for Controlling, Assurance 